\title{
ANTIDUMPING AND THE PEOPLE'S REPUBLIC OF CHINA : FIVE CASE STUDIES
}

\author{
YEOMIN YOON ${ }^{\#}$, ROBERT W. MCGEE ${ }^{\#}$, WALTER BLOCK ${ }^{*}$
}

\begin{abstract}
The People's Republic of China (PRC) has been the number one target of antidumping actions filed by the U.S. Commerce Department on behalf of various domestic industries. One reason for this special status is because the PRC is one of the world's lowest cost producers. Because of the cost structure of its industries and economy, as well as the fact that it tends to manufacture products at the low end of the quality scale, it is able to sell a wide range of products for lower prices than most competitors. Furthermore, because it is classified as a nonmarket economy, special rules must be used to determine the cost of production.
\end{abstract}

It is unlikely that the frequency of antidumping action will decline in the near future. Indeed, because the antidumping laws are becoming more widespread as a result of their adoption by every country that became a member of the World Trade Organization, it is likely that the number of antidumping actions filed against the PRC will increase in the years to come.

This paper begins with an overview and history of the antidumping laws and proceeds to examine five antidumping actions initiated by the U.S.Commerce Department against the People's Republic of China. The paper concludes with a brief commentary and recommendations.

\section{INTRODUCTION}

Antidumping laws, which punish foreign producers for selling their products in domestic markets at low prices (McGee 1993), have been in existence for decades. Since the finalization of the Uruguay Round of GATT they have taken on increased importance, and the GATT agreement included an antidumping provision to which all signatories must adhere. Before the recent GATT agreement was concluded, only about 40 countries had antidumping provisions in their domestic laws. After the Uruguay Round, more than 120 countries agreed to adopt and enforce the GATT antidumping laws. In the past few years, the People's Republic of China has been the most frequent target of antidumping actions initiated in the United States.

This paper will examine some recent case studies involving antidumping actions initiated in the USA against the PRC and attempt to determine what the frequent exercise of the antidumping laws might mean for the future.

In the past, there have been many problems with both the theory and enforcement of antidumping laws, especially in the United States. To complicate matters, the antidumping provisions adopted by GATT are somewhat different than the provisions in U.S.law, and it has not yet been determined which set of laws will prevail in antidumping actions initiated in the United States. Some

\# W. Paul Stillman School of Business, Seton Hall University, New Jersey, USA

*. Economics and Finance Department, Univesity of Central Arkansas, USA. 
Antidumping and the People's Republic of China......

commentators have suggested that adopting the GATT antidumping provisions would amount to a partial abrogation of U.S. sovereignty. Others deny that this would be the case.

Regardless of which set of antidumping provisions is utilized, there are many common features between the GATT and U.S. rules. Many of the weaknesses in the U.S. regulations have survived the Uruguay Round.

One of the major criticisms leveled against the U.S. antidumping rules is the subjectivity with which they are applied. In a case involving some Brazilian companies, more than ten different methods were used to determine the cost of production (Bovard 1991 : 129). The use of some methods resulted in finding that dumping had occurred, since the selling price in the domestic market was less than the cost of production. Yet if other methods were used, no dumping was found because the cost of production was less than the selling price. Potential targets of antidumping actions never know in advance which cost of production methods will be used to determine whether dumping has occurred, thus injecting major uncertainty into the market place (Kaplan et al 1988). It is impossible to predict in advance whether a pricing strategy will result in the triggering of an antidumping action, or whether the antidumping action, once started, will be sucessful.

Another major criticism of the U.S. rules is the arbitrariness, and the potential abuse that goes with it (McGee 1994:92-111). The government can demand practically anything and the target of the investigation must comply or face dire consequences. If the target company(ies) product 99 percent of what is demanded in the format requested, the Commerce Department can reject the entire submission and instead use what it labels the "best information available" (BIA) which, in practice is often information provided by the domestic producers that initiated the antidumping action. This BIA is often not the best information available, in spite of the name. It is often biased against the target of the investigation and is often based on estimates that violate generally accepted accounting principles or common sense.

In many previous antidumping cases, the Commerce Department has demanded vast quantitites of information with a short turnaround time. In a case involving Matsushita, it demanded that 3,000 pages of financial information be translated into English. The demand was made on a Friday afternoon, the deadline was the following Monday morning (Bovard 1991:136). Rather than comply with this impossible request, Matsushita withdrew the product from the domestic market, which pleased the domestic companies that initiated the action.

In another case, the Commerce Department sent a 66-page questionnaire (in English) to six former Soviet republics and demanded information about their uranium production (Bovard 1992). Aside from the fact that they did not have the information, it would have been illegal to supply it if they did have it. Yet they were punished for failure to comply.

Another problem with the computations used to determine whether dumping has occurred is the method by which prices are determined in an environment with rapidly changing exchange rates (Palmeter 1988). Sometimes, the methods used to compare the foreign currency to the dollar will result in a finding of dumping where no dumping would otherwise be found. This methodology may prove to be a major problem in many Latin American countries, where inflation has been institutionalized, but could be a problem in China as well, which has a much lower rate of inflation.

Many antidumping actions in the past have compared products that are not strictly comparable, 


\section{Asian Economic Review}

with the result that an antidumping action might find a party guilty where a guilty finding is not warranted. For example, Product A in China might be compared to Product B in the United States event though Product A might be different qualitatively from Product B. The fact that the products are qualitatively different does not mean that there will automatically be some discounting applied to account for the qualitative difference. Where differences are taken into account, the Commerce Department sometimes uses strange comparisons that have no basis in economics.

Where the alleged dumping has been done by companies in a non market economy, the normal methodology is to choose a surrogate country's prices, perhaps with adjustment, as a substitute for the alleged offender's costs, in an effort to determine whether the foreign producer has sold products on the domestic market for less than cost. This faulty methodology invites abuse, and is compounded by the fact that the petitioners are often the ones that choose which country is to be used as a surrogate, and which data from the surrogate country are to be examined. This procedure is especially relevant to cases involving the People's Republic of China, since the Commerce Department has on many occasions classified the PRC as a nonmarket economy.

The whole concept of selling consistently for less than fair value, or for less than the cost of production, is a curious one. First of all, fair value is determined by the interaction of buyers and sellers. Something is worth whatever someone is willing to pay for it. So asserting that a product can be consistently sold for less than fair value, when buyers and sellers are free to negotiate, is ridiculous on its face. Yet the view that something can be sold for less than fair value is not only the basis for the underlying antidumping theory, but is also punishable, even though both parties to the transaction benefit as a result of the sale. Otherwise, there would be no sale, since parties to a sale do not go into it with the idea of making themselves worse off. Consumers benefit, of course, and antidumping laws were put on the books (supposedly) to increase competition, which benefits consumers.

This doctrine, moreover, reeks of objective costs philosophy, and of its best known variant, the Marxist labor theory of value. Here, things have value insofar, and because of, the objectively priced factors of production such as land or capital, or, for the socialists, particularly labor'. But this perspective, one would have thought, has long since been confined to the dust bin of history. Things are not valuable because they are composed of valuable inputs. Any housewise who has ever had to throw out a burnt pie or roast full well knows the truth of this. Mud pies and cherry pies cost just about as much to produce as one another, yet one is of great value, the other only for purposes of illustrating economic fallacy. In certain areas of the world one can pickup a diamond merely with the effort (cost) of bending down to the ground;does this mean that the diamond is worth only a little bit given that the cost of obtaining it was so low? If you believe this, you'll believe anything.

Selling a product for less than the cost of production is almost never done, and when it is done, it is for a good reason. Any company that sells for less than the cost of production as a general policy will soon go out of business. Furthermore, if something is sold for less than the cost of production, consumers benefit, and since the antidumping laws were passed to benefit consumers, no one should complain, and certainly companies that sell their products to domestic consumers for low prices should not be punished. Yet that is exactly what happens under the present antidumping laws.

1 For eviscerations of these doctrines, see Bohm-Bawerk, 1884, particularly Part I, Chapter XII, "Exploitation Theory of Socialism - Communism". Also, Rothbond, 1995, especially his criticism of Marx, pp. 297-407. 
Then, too, there is an even more radical refutation of this dogma. The economic doctrine of alternative or opportunity costs indicates that this phenomenon is essentially a subjective one (Buchanan and Thirlby, 1981; Buchanan, 1969; Rothbard, 1993; Mises, 1966). That is, the cost of any thing is the next best option that must be sacrificed in order to obtain it. As such, no one can in principle know what the cost of anyone else is of anything. The cost of reading this article might be the nap that one could otherwise be taking, the movie one could otherwise be watching, the consulting fee one might otherwise be eaming, or whatever. This sort of thing is known only to the economic actor himself, and not to any third party. Sunken costs are but one way of illustrating this concept. No matter what it cost to create a tomato or flower, if it is presently on the verge of wilting or rotting, then it will be sold for whatever it can garner on the market, and the historical or out of pocket costs which were previously undertaken in its production are entirely irrelevant to the decision to sell. Only a government board could take an interest in the original costs of the alternatives foregone in order to create the flower or tomato.

The problem with antidumping laws is that they are used by domestic producers to prevent foreign competition. They use the force of government to either prevent foreign competitors from entering the domestic market, or if they do enter, they must either charge high prices or pay a high tariff to the government as a cost of doing business.

One reason why the antidumping laws were passed was to prevent predatory pricing. Yet the antitrust literature of the past few decades has concluded that predatory pricing either doesn't exist, or if it could exist, would benefit consumers (R.McGee 1994:138-9; Koller 1971;J.McGee 1958;Fisher 1987;Armentano 1972, 1990; Rothbard, 1993; Block,1977, 1982, 1986, 1994, 1999). It doesn't take a rocket scientist to figure it out. If a company drops its price so low as to drive out all competitors, it will gain market share and lose money on every sale. If it is able to force out all competitors, they will stay out only as long as prices remain so low that they would not be able to make a profit by re-entering the market. The only way a predator can prevent competitors from reentering the market is by keeping its prices abnormally low.

It would probably go out of business if it kept its prices low. But let's say that it was somehow able to stay in business. Consumers would benefit by the lower prices. So it is possible to conclude, a priori, that predatory pricing cannot exist in a free market, or if it did exist, it would benefit consumers. Thus, the apriori approach meshes completely with the empirical antitrust literature on this point.

It is no exaggeration to say that the entire anti-dumping hysteria is predicated upon the rationality of the doctrine of predatory pricing. The idea is that the wily, vicious and evil foreigners will sell to us unsuspecting rubes goods at very low prices. Then, when we get "hooked"on their exports, they will suddenly jack up the prices, leaving us high and dry. Were it not for our antidumping laws, the unsophisticated traders in the U.S. would be victimized by the hordes of sweater producers in Bangla Desh, steel mill owners in India, show producers in gabon.

To put in the idea in this manner is to expose it as fallacious. If there ever were a predatory

2. To say nothing of the predator himself, for expecting and counting on such rampant brainlessness on the part of other people. 


\section{Asian Economic Review}

price cutter in all of histroy, whether dealing in domestic or foreign markets, the people he exploited must have been pretty stupid ${ }^{2}$. For one thing, the targets of the predation could have aligned themselves with members of their industry in other locales. An attack on one could be construed as an attack on all. For if the predator could bankrupt one competitor through these means, he could do so with them all, eventually, one by one. For another, the targets could have cooperated with their own buyers. For as soon as they were out of business, their customers would feel the pinch of the "monopolistic" price which would soon follow. But perhaps the best way to puncture the fallacy of predatory pricing is to realize that even if there were some sort of objective price below which the predator was selling, all his targets had to do is purchase these goods from the predator himself at the artificially low price. If it costs a Rockefeller $\$ 10$ to refine a barrel of oil, but he is selling it at $\$ 2$, the rational economic actor will buy up as many at these bargain basement rates as possible. Then, when the predatory Rockefeller finally tires of losing $\$ 8$ per barrel, and tries to double price to $\$ 20$, the target will be sitting on acre feet of oil he purchased at a mere $\$ 2$. If this doesn't sound the death knell for this whole idea, then nothing ever will ${ }^{3}$.

\section{CASES}

\section{PRESERVED MUSHROOMS}

This investigation was launched in January 1998 as the result of a request by the Coalition for Fair Preserved Mushroom Trade, which is comprised of L.K.Bowman, Inc., Nottingham, PA; Modern Mushroom Farms, Inc., Avondale, PA; Monterrey Mushrooms, Inc., Watsonville, CA; Mount Laurel Canning Corp., Temple, PA; Mushroom Canning Co., Kennett Square, PA; Sunny Dell Foods, Inc., Oxford, PA and United Canning Corp., North Lima, OH. (USTIC 1998:A-3,6). Thirty-six potential PRC exporters and mushroom producers were targeted by the petitioners (A-8). Because China is classified as a nonmarket economy, surrogate country costs were used to extimate the costs of production. In this case, Indian consumption data for materials, labor and energy were used. The petitioners alleged that the mushrooms were being sold for less than the cost of production. Based on information supplied by the Coalition, the preliminary investigation concluded that there was reason to believe that the Chinese mushrrom imports were, or were likely to be, sold at less than fair value (A-8).

\section{CARBON STEEL PLATE}

Carbon steel plate investigations are quite popular with the USITC. Since 1980, at least 80 investigations have been launched against companies in numerous countries that export this product to the United States (USITC 1997a:D-3-6). In November, 1996 the Commerce Department launched the present investigation of Chinese carbon steel plate as a result of petitions filed by Geneva Steel Company and Gulf States Steel, Inc., which alleged that imports from the People's Republic of China, Russia, Ukraine and South Africa are being, or are likely to be, sold in the United States at less than fair value, and that such imports are materially injuring, or threatening material injury to a U.S.industry (USITC 1996a:A-6). At first, it was questionable whether there was sufficient support for the petition,

3. To be sure, the analysis in the text ignores the interest dividends foregone by investing money in oil. But at any reasonable rate of interest, and any large scale "predation" this scheme is surely a dubious one. 


\section{Antidumping and the People's Republic of China......}

since Section 732(c)(4)(A) of the Tariff Act of 1930 requires that the petition be supported by companies comprising at least 25 percent of the total production of the domestic like product and more than 50 percent of the production of the domestic like product produced by that portion of the industry expressing support for, or opposition to, the petition. That question was laid to rest when the petition was amended to include support from Bethlehem Steel Corporation, the U.S. Steel Group and the United Steelworkers of America.

Since China is classified as a nonmarket economy, normal value for Chinese production is based on factors of production that exist in some surrogate country. The petitioners selected Indonesia as the primary surrogate country, since Indonesia is at a comparable level of economic development and since it is a significant producer of comparable merchandise. The pertitioners were not able to obtain port unloading charges for Indonesia, so they used the lowest charge applicable to Brazil, based on a news article. Overhead, SG\&A and profit percentages were estimated using India as the surrogate country. Based on these data, the Commerce Department estimated the dumping margins to range from $10.01 \%$ to $45.84 \%$ (USITC 1996a:A-7). Under the terms of the final agreement, Chinese plate exports are limited to 150,000 metric tons between November 1, 1997 and October 31, 1998. Weighted average dumping margins at the final stage ranged from 17.33 percent to 128.59 percent (USITC 1997 a:I-2).

\section{COLLATED ROOFING NAILS}

The Commerce Department launched this investigation as a result of the petition filed in November, 1996 by the Paslode Division of Illinois Tool Works, Inc., which alleged that Chinese collated roofing nails are,or are likely to be, sold in the United States at less than fair value, and that a U.S. industry is likely to be materially injured, or threatened with material injury as a result.

Since China is classified as a nonmarket country, a surrogate country must be chosen for cost comparisons. India was chosen because its per capita gross national product is relatively close to that of China, and because India produces comparable merchandise. Using this information, preliminary antidumping margins ranged from $106.08 \%$ to $118.41 \%$ (USITC 1997 e:A-5\&6). Final dumping margins ranged from 0 percent to 40.28 percent (USITC 1997 b:A-17).

\section{PERSULFATES}

The Commerce Department launched an antidumping investigation of the Chinese persulfate industry as the result of a petition filed in July, 1996 by FMC Corporation of Chicago. Based on an examination of the evidence, it found that there was a reasonable indication that an industry in the United States was threatened with material injury by reason of imports from China (USITC 1996b:v).

Since China is classified as a nonmarket economy, a surrogate country was chosen in order to determine equivalent costs. The petitioner chose India to value factors of production, in this case, since India is the only persulfate producer among surrogate countries that the Commerce Department typically uses for the PRC. Based on comparisons of export prices with the normal values the petitioner constructed from factors of production, dumping margins were determined to range from $15.87 \%$ to $182.37 \%$ (USITC 1996b:A-6). The final determination found that Chinese persulfates were being, or were likely to be, sold in the United States for less than fair value (USITC 1997c:A-5). Dumping margins in the final determination ranged from $40.97 \%$ to $134 \%$ (USITC $1997 \mathrm{c}: \mathrm{A}-18$ ). 


\section{Asian Economic Review}

\section{BRAKE DRUMS AND ROTORS}

This investigation was launched as the result of a petition filed by the Coalition for the Preservation of American Brake Drum and Rotor A ftermarket, which consisted of manufacturers from Illinois, Califormia, Pennsylvania and Missouuri (USITC 1996c:B-3). The Coalition alleged that Chinese brake drums and rotors were, or were likely to be, sold in the United States at less than fair value. (USITC 1996c:B-4). Since China is classified as a nonmarket economy, India was used as a surrogate country to estimate some Chinese costs (USITC $1997 \mathrm{~d}: \mathrm{A}-11$ ). Based on information furnished by the petitioner, the Commerce Department found, at the preliminary level, that the Chinese were guilty, and calculated dumping margins ranging from 46.76 percent to 105.56 percent for brake drums and from 52.08 percent to 62.55 percent for brake rotors (USITC 1996c:B-5). At the final stage, termination agreements were entered into. Dumping margins for brake drums ranged from 0 percent to a Chine-wide rate of 86.02 percent. For brake rotors, the final margins ranged between zero and 43.32 percent (USITC 1997d:A-17).

\section{CONCLUDING COMMENTS}

The antidumping laws are based on a number of faulty premises. For one thing, actual dumping rarely occurs, because, if it did, the company that does the dumping would probably go out of business. There are instances where a company sells its products ,either in foreign or domestic markets, at less than the cost of production. Where this practice does occur, it is usually for good business reasons the alternative to selling below cost may be to not sell at all. This is certainly the case for wilting flowers or aging tomatoes. Very seldom do companies sell at less than cost to drive out the competition with the intent of later capturing market share. The numerous studies that have been done on predatory pricing have either found that predatory pricing does not exist, or if it does exist, it benefits consumers.

Another faulty premise is that dumping is bad for the economy. If a foreign producer does sell below cost, or for a lower price than in its home market (these are the two criteria for dumping), the practice benefits consumers - the general public. Domestic producers are harmed, but domestic producers constitute a small minority, although a concentrated one. In practice, the antidumping laws have been used as protectionist clubs by these special interest groups - domestic producers to batter the competition at the expense of the general public.

Another flaw, a philosophical one, is the concept that one producer should be punished for harming another prducer. There is a vast difference between being harmed and having your rights violated. For example, if a supermarket opens up across the street from a small, mom and pop grocery store, mom and pop will likely be harmed, but they will not have their rights violated. They have no right to sell products to consumers who do not want to buy from them. But the antidumping laws go a step further down this illogical road. They would punish foreign producers for doing business domestically if there is a mere threat of harm to a domestic industry. Thus, they are punished for something that they merely might do in the future. If such a theory were applied to criminal law in the United States, it would lead to the incarceration of anyone who fits a criminal profile whether they were actually guilty of breaking the law or not. Yet the antidumping laws regularly use such a yardstick to determine whether a foreign producer should be punished.

A number of other flaws too numerous to mention here infect the antidumping laws. But these 
Antidumping and the People's Republic of China......

flaws have been pointed out elsewhere (McGee 1993; 1994; McGee and Block, 1997). The main point is that antidumping laws have become much more important since the conclusion of the Uruguay Round and the founding of the World Trade Organization. Now, more than 120 countries have these laws at their disposal. The potential for abuse is great and growing. It is reasonable to expect that, as domestic producers in these countries become aware that they can use these laws to prevent foreign producers from offering their goods in domestic markets at low prices, they will make use of these laws, which benefit domestic producers at the expense of the general public. The antidumping laws will become the biggest weapon of protectionists as tariffs and quotas fade away. Reform is not the answer, since these laws are based on incorrect premises. The only solution is outright repeal, the sooner the better.

Unfortunately, it is unlikely that the antidumping laws will be repealed by the WTO and its $120+$ signatories in the near future. As a result, antidumping laws will have an increasingly important effect on world trade, especially in the case of China, since the PRC is the number one target of antidumping actions. Antidumping laws can become one of the major challenges to trade with China in the twenty-first century.

The Uruguay Round diminished the effectiveness of tariffs and quotas as protectionist tools, but antidumping laws have become more important. Antidumping laws are likely to become the protectionist tool of choice, and will likely be used to keep Chinese goods out of foreign markets. Thus, a major challenge to trade with China will be how to find ways to conduct business with China without running afoul of the antidumping laws, or how to circumvent the antidumping laws when they are used to block trade. These laws will likely result in high antidumping duties in many cases. These duties will have exactly the same effect that tariffs had in the past- they will increase prices to consumers and make Chinese goods less competitive in international markets. In some cases, Chinese goods will not be able to cross borders at all, and thus will have the same effect on international trade as did quotas in the past.

The best solution to this impending problem is outright repeal, as was stated previously. However, until repeal can be accomplished, ways must be found to minimize the adverse effects that the implementation of antidumping laws will have on international trade.

\section{REFERENCES}

Armentano,D.T.(1990). Antitrust and Monopoly:Anatomy of a Policy Failure. New York:Holmes \& Meier.

Armentano, D.T.(1972). The Myths of Antitrust. New Rochelle,NY:Arlington House.

Block, Walter, "Total Repeal of Anti-trust Legislation: a Critique of Bork,Brozen and Posner, Review of Austrian Economics Vol.8,No.1,1994, PP.31-64.

Block, Walter, "Optimal Export Policy for a New Product Monopoly, "Cross Cultural Management, Vol.6,No.2,1999,PP.29-32.

Block, Walter, "Austrian Monopoly Theory - a Critique ,"The Journal of Libertarian Studies : An Interdisciplinary Review, Vol.I,No.4,Fall 1977,p.p.271-279. 


\section{Asian Economic Review}

Block, Walter,Amending the Combines Investigation Act, Vancouver: The Fraser Institute, 1982.

Block, Walter, Reaction:The New Combines Investigation Act, Vancouver: The Fraser Institute, 1986.

Bohm-Bawerk, Eugen, Capital and Interest, South Holland, IL:Libertarian Press, George D. Hunke and Hans F.Sennholz, trans., 1959 (1884).

Bovard, James (1992,June 8) U.S. Protectionists Claim a Russian Victim. Wall Street Journal, P.A-10.

Bovard,James (1991). The Fair Trade Fraud. New York: St.Martin's Press.

Brown, Terry (1997) Chinese Crawfish: Let Them Dump. Loyola Student Journal of Economics, 10:2, 7-8 (Spring).

Buchanan, James M.and G.F.Thirlby, eds., L.S.E. Essays on Cost, New York: New York University Press, 1981.

Buchanan, James M., Cost and Choice:An Inquiry into Economic Theory, Chicago:Markham, 1969.

Fisher, Franklin M. (1987). On predatory Predation and Victimless Crime. Antitrust Bulletin 32, 85-92 (Spring).

Kaplan, Gilbert B,: Lynn G.Kamarck and Marie Parker. Cost Analysis under the Antidumping Law. George Washington Journal of International Law \& Economics, 21,357-418.

Koller, Ronald H. (1971) The Myth of Predatory Pricing: An Empirical study. Antitrust Law and Economics Review 4,105-123 (Summer).

McGee, John S. (1958). Predatory Price Cutting : The Standard Oil (N.J.) Case. Journal of Law \& Economics 1, 139-169 (October).

Mc Gee, Robert W (1994).A Trade policy for Free Societies: The Case Against Protectionism. New York and Westport, CT:Quorum Books.

McGee, Robert W. (1993). The Case to Repeal the Antidumping Laws. Northwestern Journal of International Law \& Business, 13 (3), 491-562.

McGee, Robert W., and Block, Walter, "Ethical Aspects of Initiating Anti Dumping Actions ", International Journal of Social Economics, 1997, Vol.24, No.6,pp.599-608.

Mises, Ludwig von, Human action, Chicago: Regnery, 1949,1963, 1966.

Palmeter, N.David (1988). Exchange Rates and Antidumping Determinations. Journal of World Trade, 22,73-80

Rothbard, Murray N., Classical Economics: An Austrian Perspective on the History of Economic Thought, Hants, England;Edward Elgar, 1995, Vol.ll.

Rothbard, Murray N., Man, Economy and State, Auburn AL: Mises nstitute, 1993.

United States International Trade Commission. 1998. Certain Preserved Mushrooms from Chile, China, India, and Indonesia. Investigations Nos. 731-TA-776-779 (Preliminary), Pub. 3086 
Antidumping and the People's Republic of China......

(February).

United States International Trade Commission. 1997a. Certain Carbon Steel Plate From China, Russia, South Africa, and Ukraine. Investigations Nos.731-TA-753-756 (Final), Pub.3076 (December).

United States International Trade Commission. 1997b. Collated Roofing Nails From China and Taiwan. Investigations Nos. 731-TA-759(Final)., Pub 3070 (November).

United States International Trade Commission. 1997c. Persulfates From China. Investigation No. 731-TA-749 (Final), Pub.3044 (june).

United States International Trade Commission. 1997d. Certain Break Drums and Rotors From China Investigation No.731-TA-744 (Final), Pub.3035 (April).

United States International Trade Commission. 1997e. Collated Roofing Nails From China, Korea, and Taiwan. Investigation Nos.731-TA-757-759 (Preliminary), Pub. 3010 (January).

United States International Trade Commission. 1996a. Cut-to-Length Steel Plate from China, Russia, South Africa, and Ukraine. Investigations Nos.731-TA-753-756 (Preliminary), Pub.3009 (December).

United States International Trade Commission. 1996b. Persulfates From China. Investigation No.731-TA-749 (Preliminary), Pub.2989 (August).

United States International Trade Commission. 1996c. Certain Brake Drums and Rotors From China. Investigation No. 731-TA-744 (Preliminary), Pub. 2957 (April) 